\title{
Chapter 8 \\ Eco-engineering for Water: From Soft to Hard and Back
}

\author{
Kelly Shannon
}

\section{Introduction}

Water-based urbanism, that is, the design of cities around the role and dynamics of water, has been a powerful urban impetus in many parts of the world. As a consequence of the location of cities along major rivers, on seacoasts, and in inland and coastal deltas, water urbanism is indeed a predominant part of the history and current status of many cities. However, water urbanism has changed and continues to face pressures to evolve. These pressures include a shift to urbanism based on transport by roads, and the need to adapt to changing climate and rising sea level. This chapter addresses changes in the paradigm of water-based urbanism, and summarizes opportunities to improve urban resilience by reclaiming key insights from the traditions of designing with water, as exemplified in Europe and South and East Asia.

\section{Drivers of Paradigm Shift}

Extreme weather events across the globe have become commonplace news. Devastating hurricanes, cyclones, tropical storms, landslides, tsunamis and floods have heightened awareness of humankind's transformation of the environment. From the Gulf Coast's Hurricane Katrina in 2005, to the Sundarban's Cyclone Sidr in 2007, to Japan's Sendai Tsunami to the floods wreaking havoc in and around Bangkok in 2011, the world is coming to terms with the significant humanitarian, environmental and financial consequences of natural disasters. The failures of engineered levee systems, the destruction of protective coastal mangrove forest,

\footnotetext{
K. Shannon $(\bowtie)$

Oslo School of Architecture and Design, AHO Maridalsveien

290175 Oslo / Pb 6768 St. Olavs plass 0130 Oslo, Norway

e-mail: Kelly.Shannon@aho.no
} 
the sheer power and unpredictability of events along the Pacific Ring of Fire and the rapid shift of water-based urbanism to road-based urbanism suggest the alternative to "build back better." Mitigation can become proactive rather than reactive if urban design and planning anticipate risk and exposure-designing for resilience by remolding landscapes and re-constructing settlements to bend from hazards, but not break. There is clearly ample room for innovation and experimentation that is "safe to fail" (Lister 2007), which is heralding a new approach to recovery planning (see Topos 76 2011).

At the same time, the "hygienist city" or "bacteriological city" initiated by nineteenth century public health and sanitation concerns is being radically rethought. Engineered hydraulic infrastructure, largely "hidden beneath city streets or relegated to those marginal spaces on the urban periphery where 'noxious trades' became concentrated in the wake of successive legislative measures or tackle urban pollution" (Gandy 2004), is antiqued and in dire need of maintenance and re-scaling to meet present demographics. Paralleling the development of a mechanized waste and storm water network, the natural hydrological cycle also has witnessed a number of changes due to decreased infiltration and groundwater recharge, and the disturbed pattern of surface and river runoff. This has been because urbanization requires the construction of extensive impervious surfaces and, over time, natural water bodies have been channelized, piped, covered or even filled.

As a partial reaction, since the 1970s, much attention has been paid to storm water management. There has been a break with the traditional, reactive, centralized "end-of-pipe" conveyance systems which evacuate water from urban areas as quickly as possible, towards a decentralized and proactive approach of detention, retention and recharge which protects the natural water cycle and ecological system by the introduction of local source control (Andoh and Declerck 1999; Niemczynowicz 1999). Integrated resource water management is defined as "a process which promotes the coordinated development and management of water, land and related resources, in order to maximize the resultant economic and social welfare in an equitable manner without compromising the sustainability of vital ecosystems" (Global Water Partnership 2011). Yet, to a certain degree, integrated resource water management, reinvents and rephrases what during so many episodes of urban development in the past had already been realised. The convergence between urban development and different forms of water management and engineering was often linked to a combination of functional, utilitarian and symbolic uses of water.

For example, the research of Katherine Rinne (2011) on the waters of Rome reveals the inextricable relationship of waterworks to power, control, urban development, and urban design. Between 1560 and 1630, when the Catholic Church sought to exemplify its prestige through the restoration of the city, it developed Rome's water infrastructure as the primary vehicle to transform the medieval backwater into one of Europe's preeminent cities. The visible aqueducts, fountains, bridges; and invisible conduits, distribution tanks, sewers; formed an integrated water infrastructure system that was both a symbolic and physical armature that effectively ordered Rome's public space and prioritized the city's development. The city's rebirth through water infrastructure relied heavily upon recalling the paradigm 
of Rome's past-the 11 ancient aqueducts, hundreds of fountains and numerous sewers that had once ornamented and served the ancient city (Rinne 2011; see also McGrath, Chap. 11, this volume).

During the era dominated by modern functionalism, water was to a large extent de-symbolized. With the contemporary crisis of functionalism and modernism alike, and hard engineering as one of their primary instruments, the symbolic meaning of water is not necessarily being resurrected, but water-as a crucial and irreplaceable natural element par excellence, is at least reappearing in urban development discourse (Viganò, Chap. 25, this volume). It is no longer engineered away, but is again an integral and indeed value-engineered part of urban reality.

More fundamentally, a renewed relationship between city and nature (De Meulder and Shannon 2009), between water, nature and society (Swynegedouw 2004), and between metropolitan nature, capitalism and social power (Gandy 2002) has thrown into question the complex entanglement of relationships that constitute urban nature. Sometimes nature and city are seen as "reunited" (www.biotope-city.net). At the same time, water is also on the agenda from other perspectives. We are constantly reminded of other effects of global warming and rising sea levels - uneven distribution of scarce water resources and the extreme problems of drought, disturbed terrain and affected watersheds, pollution, water storage and harvesting. Anthropogenic actions have had a pervasive and generally negative effect on water systems, from local creeks and streams to major rivers and estuaries, and shorelines to freshwater and saltwater wetlands and as well to oceans and even the polar ice caps. Water has become a strategic and ever shrinking resource, and clean water has been touted as the twenty-first century's “oil” (IPCC 2007; Feyen and Shannon 2008).

Finally, in the past several decades, water has forcibly re-captivated the contemporary agenda of urbanism, beyond a cocktail of nostalgia and ecological concerns that often resulted in the transformation of post-industrial harbor and riverfront sites into commercially-successful leisure playgrounds. Architects, urban designers and landscape architects are more creatively imagining the city in relation to water. Projects that reunite engineered and natural processes and strengthen existing logics of sites are becoming the base for new regional and urban forms. A "soft engineering" approach is advocated as a way to work with the forces of nature, in order to reduce or mitigate the likely impacts of natural disasters, while the revised development of cities is to be guided by new interplays of landscape, infrastructure, and urbanization (Shannon 2004; Reed 2006; Bélanger 2009; Ellin, Chap. 4 this volume).

Historically, water structures, whether natural or artificial, were the keystones of urban construction. The definition of the city as shaped by water has been a cornerstone of urban design (De Meulder and Shannon 2008). For example from the plan of Alexandria by Dinocrates in 331 B.C. to the plan of Washington by L'Enfant in the eighteenth century, city structure was inconceivable without rivers or canals. Indeed, the fifteenth century Italian polymath Leonardo da Vinci established urban prototypes in which rivers were central structuring elements. Water urbanism has a parallel tradition grounded in an intelligence borne of necessity that led ancient civilizations to seek a balance in creating their settlement structures with, by and through the 
constructed landscape. Ancient civilizations had ingenious methods of water resource management, often simultaneously addressing pragmatism, urbanism and symbolism. Innovative hydrological engineering, an understanding of topography and seasonal weather patterns had profound implications for the form, growth and vitality of human settlements. There are invaluable lessons for today in the world's legacy of indigenous water management methods.

\section{Indigenous Water Management}

In Asia's tropical monsoon belt, waterworks are huge infrastructure projects that supported the region's thriving wet-paddy rice civilizations for millennia. Lowtech rational logics using the dynamics of erosion and sedimentation led to the efficient use of seasonal watercourses, storage of monsoon rains for use in dry seasons and building methods which adapted to flooding (Thaitakoo et al. Chap. 26, this volume). Wet rice cultivation requires a relatively equitable distribution of water and a system of canals, dikes, irrigation canals, terraces, and locks to regulate water levels. Clearly, water management and settlement were strongly intertwined in the Asian context.

Angkor Thom, the legendary capital of the land-based Khmer Empire (AD 8021432), has an urban structure, settlement pattern and monumental architecture that is inseparable from its complex irrigation system. Ensconced in Hindu-Buddhist cosmology, the city's hydrological infrastructure connects the fertile alluvial Angkor plain to the northern Kulen Hills and to the southern Tonle Sap Lake. Tonle Sap is connected to the rhythms of the Mekong River and is unique in that it reverses the direction of its flow twice a year with a surface increase of 4-6 times and a water level rise of 7-11 $\mathrm{m}$ in the flooding season. The well-known temple city remains are merely a component of the vast territorial development that recent French archaeological research has documented - where "the modest ruins of hundreds of small sanctuaries, thousands of ponds and earth platforms are a testimony to the myriad of village settlements that were part of a dense and complex network of roads, canals, dams and reservoirs (barays)" (Pottier 2008). The Khmers' development of a carefully engineered network of barays were connected to the natural river regime and were a means of both irrigation and transport. Trapeang were excavated ponds for collecting rainwater used by Khmer households for drinking, bathing, watering animals, small-scale hydro-agriculture, etc. The barays and the trapeang reveal an ingenuity to marry a productive agricultural/irrigation system with a settlement structured as a sacred/Khmer landscape.

In other regions of Asia, feng shui, the science of "wind and waters" was already recognized at the beginning of the Han Dynasty in 206 BCE. Feng shui has been utilized to situate settlements and adjust features of the cultural landscape to minimize adverse influences and derive maximum advantage from favorable conjunctions of form. Feng shui combines elements of Confucianism, Taoism, and Buddhism to determine the best disposition of "everything under heaven." In his monumental 
Science and Civilization in China, the renowned geographer, Joseph Needham, describes how feng shui is a complex ordering system that emanates from the geomancer's analysis of the morphological and spatial expressions of the $c h$ ' $i$ (cosmic breath) in the surface features of the earth. Geomancers, diviners of auspicious sites, are those endowed with the ability to read the dynamic powers of the genius loci's specific topological features and their relation to heavenly bodies. Feng shui strives to structure the relationship between the natural and social environments (Needham 1956). Tied to feng shui is the vaunted marriage of water and city and a number of legends attached to the founding of cities, the interventions of the gods, and the fanciful tales of kings. In addition to the ordering axes established by relations to topography, the siting promoted by feng shui follows commonsense logic: proximity to a river course supplying clean water, minerals, fish for food, and prosperity through transportation and communication links; protection from cold northerly winds and malignant spirits by way of mountains, hills, or trees; and a south-facing platform or high ground to have ample access to light and air and protection from floods. For example, the 1394 citing of modern day capital of South Korea, Seoul, then called Han Yang, followed the principles of feng shui (Fig. 8.1). Han Yang was surrounded by four inner mountains and four outer mountains with the Cheonggye stream flowing through the middle. Functionally, the Han River offered good accessibility to the rural areas allowing the sovereign to easily collect taxes (Kim and Han 2012). The stream also fulfilled the symbolic role as a border between the commoners living in the south and the aristocracy in the north.

A large part of Asia may be classified as what Karl Wittfogel, the renowned Frankfurt School historian and Sinologist, termed a "hydraulic civilization." Curiously, Wittfogel's term came not from the region's monsoon areas, but was specifically developed from his research in the naturally arid regions of China. In such contexts, according to him, only an obedient, nearly enslaved citizenry could possibly have supplied the labor needed to operate and maintain the irrigation canals and dikes on which intensive agriculture depended and where centralized state authority emerged from the needs for water engineering and control; good water management and despotism were interdependent. The comprehensive system of the "hydraulic civilization" employed extensive labor in lieu of taxation, which placed a constant upward pressure on population growth. This resulted in productive water works for irrigation and drainage and protective water works for flood control, but also provided drinking water and conduits for transmission and mingling of waters. Digging, dredging, and damming led to significant remoulding of the ground plane to create adaptive landscape strategies (Wittfogel 1956).

Researchers Kongjian Yu, Zhang Lei, Li Dihua of Peking University indirectly apply Wittfogel's thesis to the millennia-old water-management practices of China's Yellow River alluvial floodplain. They offered analytical and interpretative readings of indigenous adaptive landscape strategies: siting settlements on high ground, constructing walls and protective dikes, and preserving or digging ponds within cities which are, in their own words, "universally applicable strategies [for] facing global warming and regional climate change as well as practical landscape strategies" (Yu et al. and 2008). They identify three water city typologies: water-within-city, 


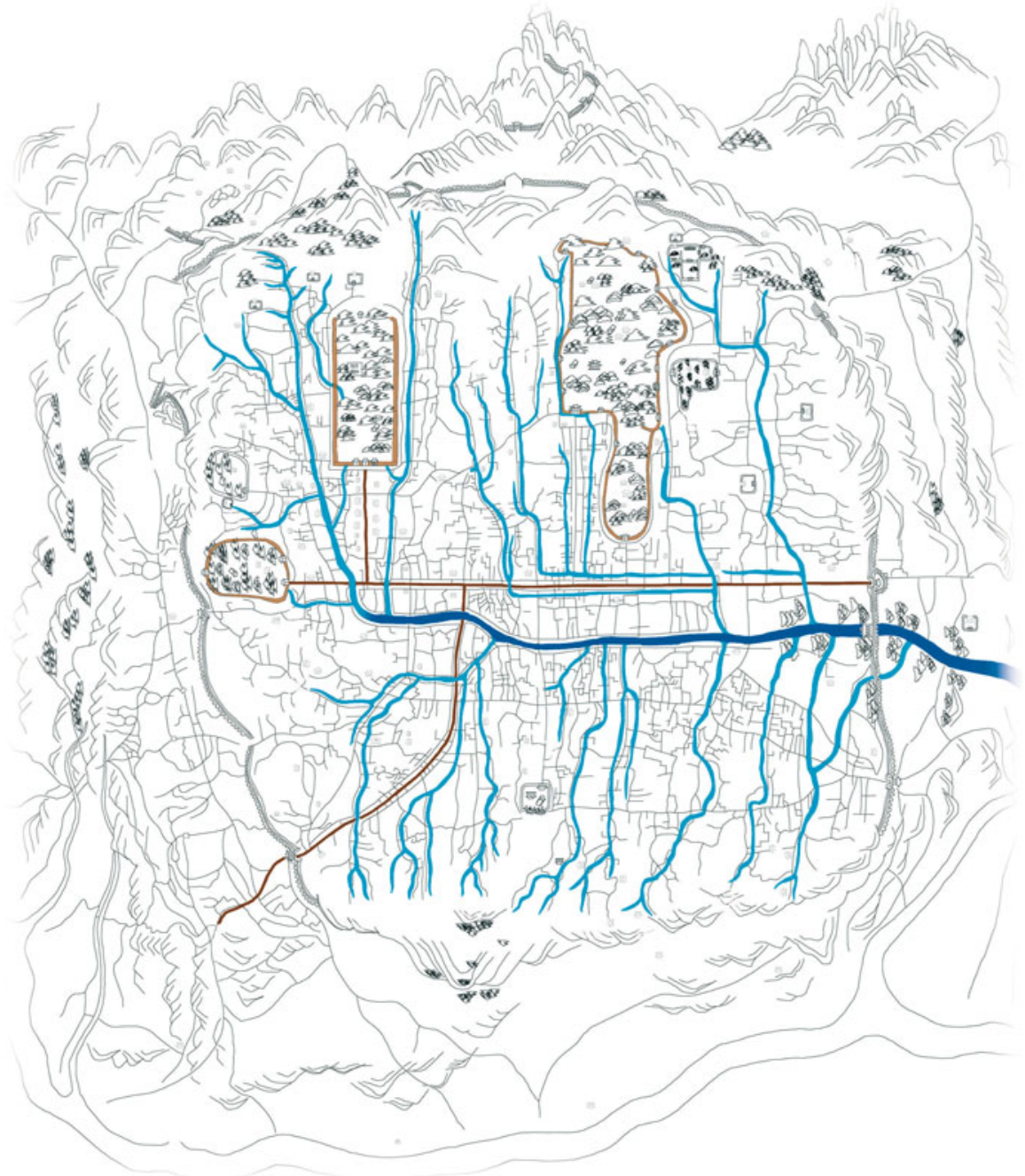

Fig. 8.1 Seoul, South Korea: More than 600 years ago, Seoul was chosen as the capital of the Chosun Kingdom and strictly adhered to the principles of feng shui. It was structured by a series of waterways and mountains, including the Cheonggyecheon River (shown in dark blue; cheon means a stream in Korean) (Source: Prof. Soo Hong Noh, the Cheonggyecheon Museum and Seoul Development Institute)

city-in-water, and yin-yang city, which developed due to financial restrictions and available where land stewardship and an art of survival translated into a minimal defence approach to "make friends with water" and combat floods.

Wittfogel's larger conceptual frame applies to many regions in Asia as does the notion that important settlement structures were founded along water bodies. In addition to the founding of cities in proximity to rivers, in deltas and along coasts, 
in South Asia, the architectonic articulation of step-wells, ghats and tanks are a successful marriage of the rational and pragmatic with the social, cultural and religious (Hegewald 2002; Livingston 2002). Engineering logics led to the development of efficient forms of step-wells-where very deep receptacles combat evaporation and harvest natural rainwater. These infrastructures are also public spaces, since many of the step-wells were strategically located along caravan trade routes and were overnight resting and gathering places. Over time, they became elevated to the status of social and religious monuments; they were highly decorated and served much more than utilitarian needs. In villages, traditional tanks were not only water reservoirs used in daily domestic routines for drinking, bathing and washing, but also used for irrigation and fishing (Shannon and Manawadu 2007). Ghats, steps leading down to a body of water, are both utilitarian and symbolic. Perhaps the most well-known ghats are those in Varansi, Hindu India's most holy city (Fig. 8.2). Seven kilometers of ghats stretch along the Ganges River, connecting land to water, city to nature and profane to sacred. Along larger, more profane rivers, ghats are major economic resources, interspersed along concrete embankments, bustling with activity and serving as hubs for formal and informal transport and commerce. Gently sloping surfaces and steps operate as landing places for different sized boats, platforms for drying laundry and recyclable plastic bags, curing bamboo, places for washing and other domestic activities and areas for sitting, fishing and selling wares. Informal vendors align access-ways and create an animated bridge between water and land.

An illustration of the region's ingenious tank system developed in Sri Lanka as early as the first century AD. The Singhalese settled in the inhospitable "dry zone," the flat lowlands surrounding the central highlands, where the construction of water retention reservoirs was a necessity. Regal cities developed with a sophisticated relationship between agricultural and reservoir systems, built form, and the natural landscape. The temples/stupae, monasteries, housing for royalty, royal water gardens housing for commoners and reservoirs were arranged in the territory according to Buddhist principles. The ruins of the royal cities of Anuradhapura and Polonnaruwa are testaments to the legacy of Singhalese water management where the agricultural, religious, and engineering aspects of the tank system were interdependent and worked hand-in-hand with urbanization (Shannon and Manawadu 2007).

The emphasis on Asian cases in this chapter reflects the firsthand knowledge of the author. However, there is obviously a much broader and extremely valuable heritage of ancient water management throughout the globe from which there are invaluable lessons. These examples stretch from the qanants of Persia and other techniques of water transmission and distribution in the arid and semi-arid desert regions (Lightfoot 2000), to the geologic water storage marvels in pre-Columbian Peru, to the pre-Hispanic agri- aqua-culture of the Maya lowlands (Scarborough and Gallopin 1991), to ancient water catchment techniques of the Mediterranean ecosystems. These examples attest to the wide-ranging legacy of the inter-relationship between water and land management, particularly as reflected in agricultural practices, watershed management, rainwater harvesting and micro-catchments. 


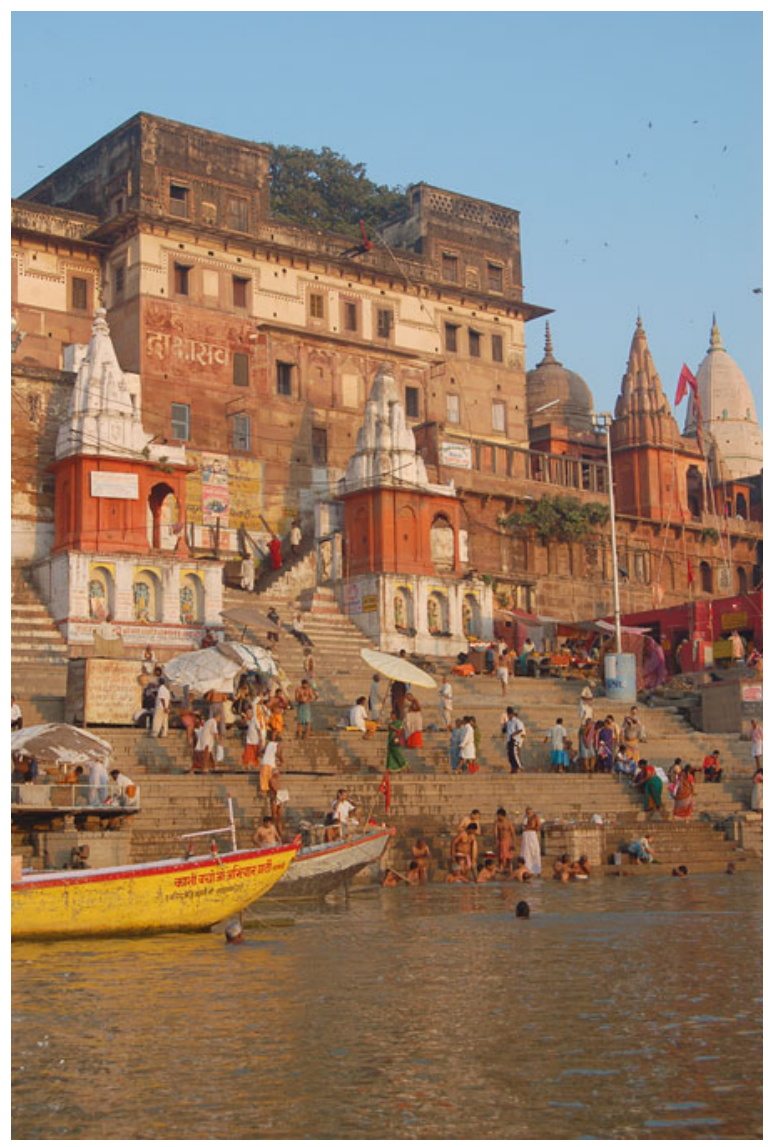

Fig. 8.2 Varanasi, India: Varansi, the most holy city of Hinduism is interspersed with $7 \mathrm{~km}$ of ghats on the curve of the Ganges River, connecting land to water, city to nature and profane to sacred (Photo credit: Thomas Feys)

\section{Contemporary Strategies in Northern Europe}

In recent years, there have been a number of water management projects that have deviated from business as usual and made a shift from hard engineering to softengineering. Slogans such as "room for water" and "space to the river" have taken precedence at the territorial scale and in terms such as SUDS (Sustainable Urban Drainage Systems) and eco-swales have become part of urban design vocabulary. Reconstructed wetlands, aerated lagoons, flood adaptive landscapes and rainwater gardens are all concepts that work with natural forces in the development of a resilient water-based urbanism. In many instances they are experimental terrains that simultaneously accommodate development pressures and ecological concerns. In the European context, there are a number of innovative projects that marry water 
challenges and both the need for further industrialization, as exemplified in a case of the Port of Antwerp, and deindustrialization, as revealed in a project along the Seine River in France.

Two design projects address the dilemmas of climate change and rising waters in the Scheldt River Basin and the desire to enlarge the public realm of Antwerp region. The first project is a consequence of European regulations which stipulate that any extensions to Antwerp's harbor are to be compensated with open space in the neighboring area. On the Dutch-Belgian border in the municipality of Beveren, between Antwerp's extension on the left bank of the Scheldt and the mudflats of Saeftinghe, both Prosper Polder and the Doel Polder are to be returned to nature. In 2007, the OSA/RUA Research Group of the Department of Architecture, Urbanism and Planning, University of Leuven won the commission to develop an "image quality plan" to be developed in parallel with the civil-engineering procedure of depoldering. Existing dykes are cut and dismantled so that room is created for the flow dynamics of the Scheldt. Simultaneously, new dykes are constructed in other locations to protect from those same flows and the entire new hydrological regime of the poldered landscape. Meanwhile, the engineered dykes are sculpted to accommodate various types of access to the surrounding landscape and to differentiate landscape and settlement morphologies. The existing cultural landscape is to be transformed into three types of landscape: a submerged landscape of mudflats and salt marshes, a controlled tidal area and a semi-polder with reservoirs. The recreated nature reserve is to become a bird-watchers haven, a weekend escape, a place to observe wetland dynamics. The reconfigured villages will host eco-tourism and the existing structure of gardens and orchards will be expanded to structure an enlarged public realm. Engineering, earthworks, urbanism and landscape are merged into a highly engineered waterworks machine, emblematic of twenty-first century "nature compensation" policies (Fig. 8.3).

The second project is for the quays of the Schedt River itself and an opportunity to redesign the riparian zone and the city/river interface. PROAP Landscape Architects, WIT Architects, D-Recta and Idroesse won an international competition in 2006 with a project that sought to develop the embankment as a refuge, not as a typical commodified riverfront, to protect the city, and mark the frontier between the city and quayside as a civic element (De Meulder 2008). The project, now being realized, deals with the technical issues of stabilizing the quay walls to meet safety standards and raising the walls $90 \mathrm{~cm}$ to deal with predicted flooding. At the same time, it choreographs a unity of diversity via a "composition of a melody of quays as keys" while preserving the existing character of the void. The new "quays as keys" toolbox works with the river's great tidal range of $5 \mathrm{~m}$ and the $6.7 \mathrm{~km}$ long by $100 \mathrm{~m}$ wide swath distinguishes between always dry and potentially wet areas. "The tides of the city become the breath of the quays" (De Meulder 2008). The "keys" are likened to piano keys, or modular profiles that are strategically developed to maintain and shape the decompression zone between the city and the river. Depending on water level, these elements - which often only have a slight gradient towards the river - can be flooded to varying degrees. Ten distinct "key typologies" or embankment sections have been developed with fixed, mobile and floating components. These 


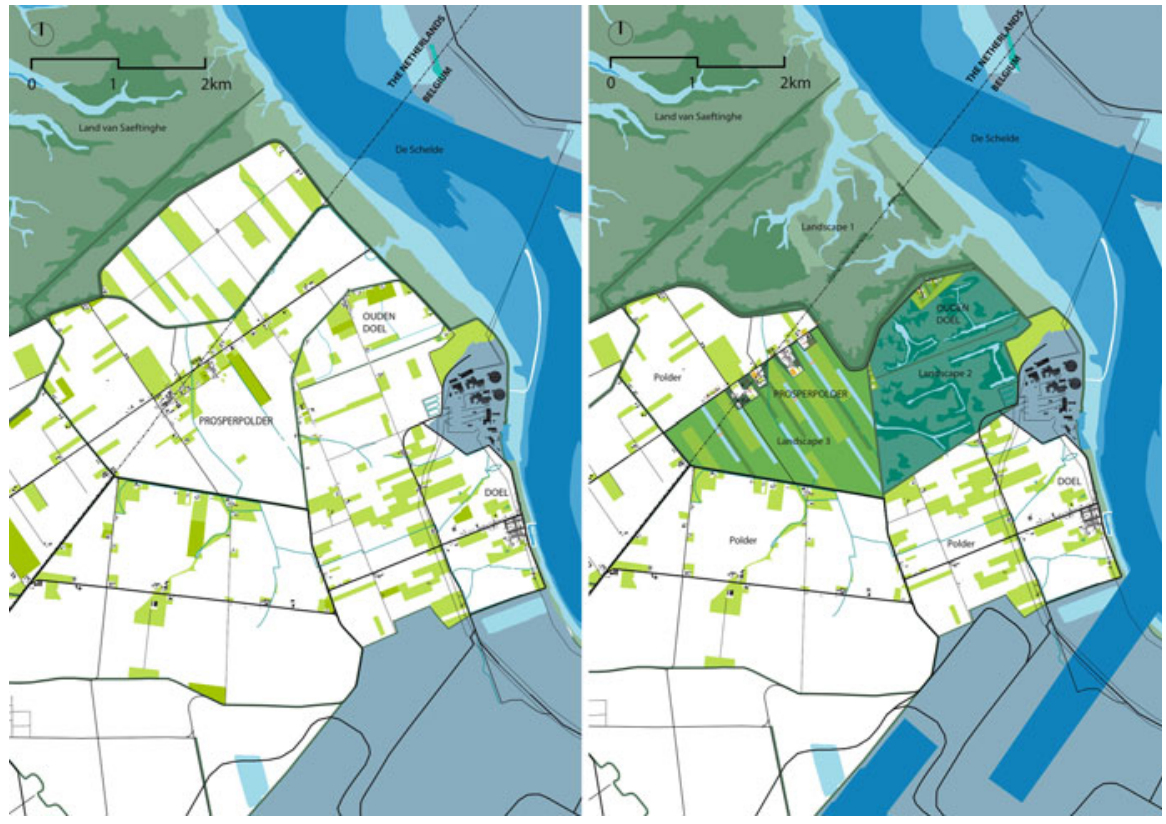

Fig. 8.3 Beveren, Belgium: The Schelde River basin straddles Dutch and Belgian territories. Antwerp's port expansion on the left bank of the river calls for "nature compensation." The poldered landscape includes agricultural fields, a number of hamlets and a nuclear power plant (left). The proposal (right) reconstitutes landscapes (natural and settled) and their interplay, with a new relation of dykes, water qualities (tidal, brackish and fresh) and levels, and hamlet structures (Source: OSA/RUA 2007)

repeating typologies create different spatial experiences and encourage diverse development along the river, while maintaining continuity (Fig. 8.4).

Another project, focused on storm water management, emerges from a project of deindustrialization, brownfield redevelopment and urban renewal in France. The landscape architects Agence Ter have developed a project that collects the rainwater from a 50 ha area into a magnificent floodable public park. The Parisian suburb of Boulgne-Billancourt, on a meander of the Seine River, is undergoing massive redevelopment where the Renault production facilities once stood. The Parc de Trapèze $(700 \times 90 \mathrm{~m})$ is the primary spatial organizing element of a new residential quarter of the recovered brownfield site. The large basin appears to let the nearby Seine invade its spaces, forming an artificial arm of the river that can serve as an outlet for the waters as it floods (Fig. 8.5). However, the water is actually stormwater and comes from three sources: rainwater from the ground and roofs from privately owned plots; rainwater from public pedestrian areas; and rainwater from asphalt roads. The first two are channeled to the park via open-air courses and the latter by way of a filtered drainpipe.

The entire neighborhood was designed $1.6 \mathrm{~m}$ above the natural terrain with the park appearing both as an urban balcony and as a submersible garden which forms 

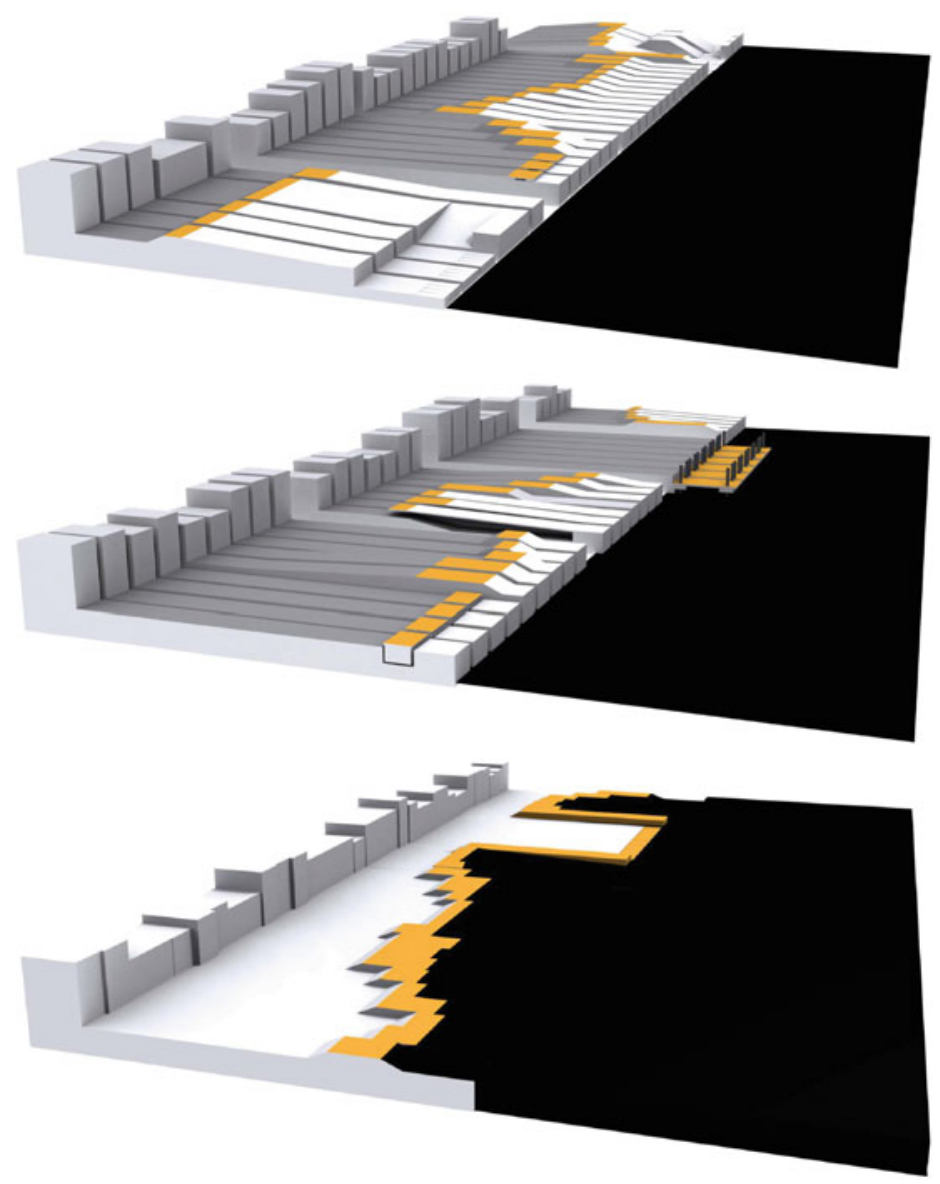

Fig. 8.4 Antwerp, Belgium: "Quays as keys and the composition of a melody." Based on 10 distinct "key-typologies," the quays planning game is simultaneously a powerful and playful tool. The proposal defines a genetic code, based on a system of principles and rules rather than a finished, immutable work. (Source: WIT/PROAP/D-Recta/Idroesse)

ponds and marshy areas around 'islands' with various environments-flowercovered prairies, peat bogs and orchards-which shrink or grow in size depending on the level of the water table. The constantly moving geography hosts a rich biodiversity and at times of peak flooding, becomes a harbor. The low-tech, low maintenance hydraulic system as the core of the urban structure required the political will of the client (SAEM Val de Seine) and the cooperation of the urban designer Patrick Chavannes and the infrastructure planner Thierry Leverne with Agence Ter. The resulting modern expression of the quay with its inhabitable pontoons and urban furniture, juxtaposed with the changing ecologies of the submersible garden is a foil to the dense housing and, like the Antwerp Quays, serves as a space of decompression. 


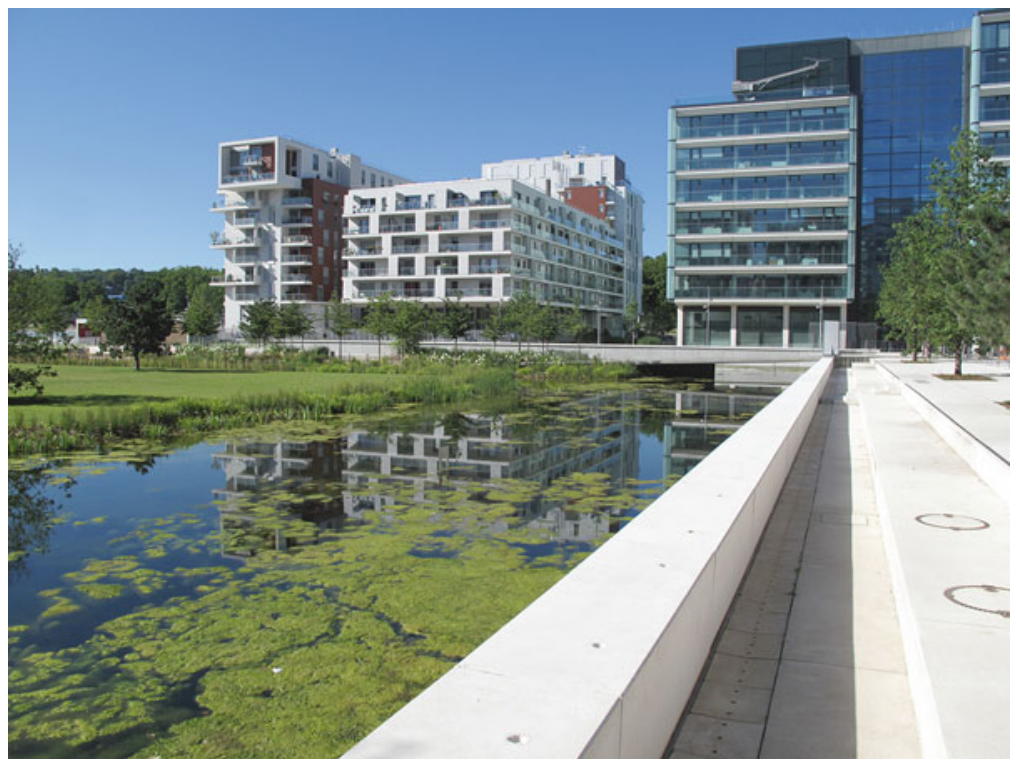

Fig. 8.5 Boulgne-Billancourt, France: The large basin serves as a connector or public space for the area and a collector of storm water. Vegetation was carefully chosen to work with both dry and wet conditions and the urban architecture is similarly responsive to changing water levels in that concrete surfaces and wooden benches are easily cleaned after they been submerged in the floodable park (Source: Agence Ter)

\section{Contemporary Strategies in Vietnam and China}

Throughout Asia, as evidenced above, the relation of urbanization to water once held a privileged position. Today, in a period of economic liberalization and transition from tradition to modernity, water is often regarded merely from a technical and engineering aspect. There are a number of predictable challenges: adopting an integrated river basin approach, greater adaptation to water-related vulnerability, more efficient services for irrigation and domestic water supply, and curbing water pollution with its health impacts on the poor (WEPA 2008). In addition to the ill-effects of domestic and industrial water pollution, dam and road construction, dredging, over-fishing and destructive fishing techniques, and intensive aquaculture, the region's extensive water network is severely compromised by the scale, scope and speed of urbanization. As technology and money now allows, bridges are spanning Asia's numerous rivers and the relation of city to water is acquiring new meanings. At the same time, water bodies are under threat as lowlands are indiscriminately filled to support urbanization. As well, illegal encroachment on water-bodies further alters ecologies and inevitably affects the severity and frequency of flooding, not to mention an increase in environmental degradation and pollution. And, the millennium-old reflective, symbolic and spatial qualities of water are often sidelined for more "pressing concerns." Four examples in Vietnam and in China are presented. 


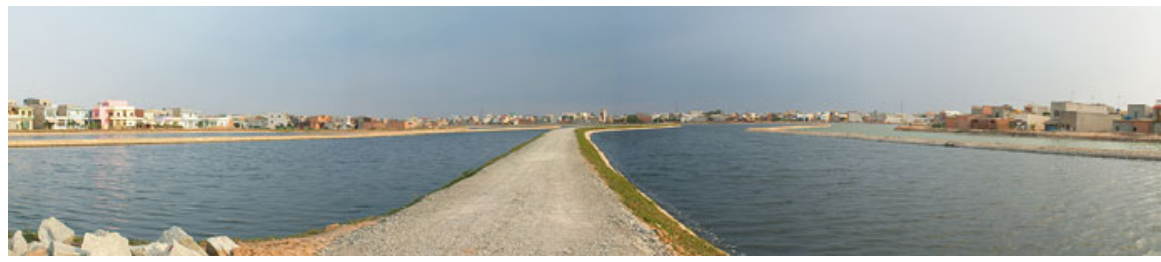

Fig. 8.6 Ho Chi Minh City, Vietnam: The expansive landscape of the aerated lagoon is a rarity in Vietnam's mega-city of 8 million including illegal residents. The maturation ponds, separated by small dykes, are ringed by sites-and-services and informal housing neighborhoods (Photo credit: Kelly Shannon)

They span both the urban design scale and territorial scale of new cities. These contemporary design projects explicitly address water challenges and create interdependent urban/water morphologies (Shannon 2008).

A unique large-scale pilot project in Ho Chi Minh City simultaneously addresses several aspects of water and the urban context. The 33.2 ha aerated lagoon provides a low-cost alternative for waste water purification. It is a place of decongestion, a "green lung" in an otherwise dense and rapidly urbanizing district, a reservoir for the seasonal monsoon rains and also has an edge that serves as programmed recreation and open space for nearby residents. As a large defined and partially controlled water body, it is also nearly guaranteed to remain an expansive open space-a rare fact in the periphery of Vietnam's rapidly expanding megacity (Fig. 8.6). The project was part of a larger bilateral development project (1998-2006) between Vietnam and Belgium that included a series of strategic urban projects connected to the upgrading of the Tan Hao Lo Gom (THLG) Canal. The lagoon treats wastewater of the Den Canal, which literally translates to "black" canal, a $4 \mathrm{~km}$ long arroyo located north of the THLG basin. The site of the lagoon, already a natural wetland, was identified as one of the last remaining open spaces in the northwest urban periphery. The constructed project utilizes aerated lagoon and stabilization pond technology, which capitalizes on natural processes and low-tech techniques of simple pumps and gravity to move the water through a sedimentation pond and three consecutive maturation ponds over the course of 11 days. The system boasts low investment, operation and maintenance costs and low production of sludge. Technically, an aerated lagoon is a holding and/or treatment pond with artificial aeration, to speed up the natural process of biological decomposition of organic waste by stimulating the growth and activity of aerobic bacteria to degrade organic waste. The energy for the process is harnessed from the intense sun and wind-the system requires only $1 \mathrm{~m}^{2}$ per inhabitant in HCMC. The cleansed water is then suitable for irrigation purposes and local residents also use the last maturation pond as a fishpond. Neither odor nor noise pollution is generated by the facility (Shannon and Legrand 2007).

In China, river restoration projects are beginning to receive a great deal of attention. Rivers in China once had a revered role - in cartography, history, mythology, festivals, cities, and everyday life. They were the center of public life. However, since the 1970s, a great number of the country's rivers have become horribly polluted by 
sewage and waste, which has resulted from continuous industrial development and urban population growth. As a consequence, with the depletion of regional water sources, water quality has drastically declined, rivers have subsequently dried, and channels have become blocked by solid waste. China's most renowned contemporary landscape architect, Beijing-based Kongjian Yu, Dean of Peking University's Department of Architecture and Landscape Architecture and head of Turenscape has been creating projects to renaturalize rivers throughout the nation.

In Qian' an City, at the southern foothills of the Yanshan Mountain, on the right bank of Luan River, northeast of Hebei Province, the river's water was out of sight due to topography and high embankments. Yet, the river made its presence known since it is notorious for unpredictable flooding. Meanwhile, the source of Qian'an was a tributary of the Luan, the Sanlihe River, a more calmly flowing river which before 1973 had crystal clear water from the groundwater recharge. The flow of the Luan River was never a source of either drought or flood; on the contrary, it provided rich water resources for nearby industries and agriculture. However, as industrialization and urbanization progressed, the Sanlihe suffered the same fate as rivers throughout China. It became the city's back side_-neglected, a sewer and waste-disposal site. It no longer resembled a river. The water disappeared and its meaning as a life source vanished.

In 2007, Turenscape was commissioned to recover the Sanlihe River and a $13.4 \mathrm{~km}$ long by 100-300 m wide greenway now serves as an exemplary project of how a neglected landscape can be recovered as an ecological infrastructure. Its restored ecosystem capacity mediates flood and draught, provides habitats for native biodiversity, integrates pedestrian and bicycle paths for commuting and recreational uses, creates spiritual and aesthetic benefits, and catalyzes urban development. The linear park covers approximately 135 ha and benefits a population of approximately 700,000 . The existing trees on the site were saved and the riverbanks were transformed into a number of tree islands connected by boardwalks (Fig. 8.7). The project used low-maintained native vegetation, lush water-grasses, and wild flowers. Along the greenbelt are pedestrian and bicycle routes fully accessible to communities along the channel. The urban slow-transportation network creates harmony between humans and nature in the city of a new era. The water management of the project is noteworthy. The design for the greenway took full advantage of the existing natural elevation change between the Luan riverbed and the city. A fountain was made through a pipe that goes under the high embankment, so that a constant controlled amount of water will make its way through the city before running back to the Luan River at the lower reach. This strategy turns the Sanlihe into a "scenic byway" of the larger Luan River and transforms the dangerous natural force into a pleasant amenity. Secondly, the existing concrete channel of the river was removed and a multiple watercourse riparian wetland system was created. Also included are clusters of emerald-like wetland parks at the edge of the main watercourse that regulate floods and collect and dissipate urban storm water runoff. When the river's water level drops to its lowest point, pools of water remain in the emeralds as wetlands, creating a "green river." Furthermore, these wetlands work as an ecological purification buffer for urban storm water runoff from both banks. These meandering natural waterways, at various elevations, create diverse habitats for wildlife. 


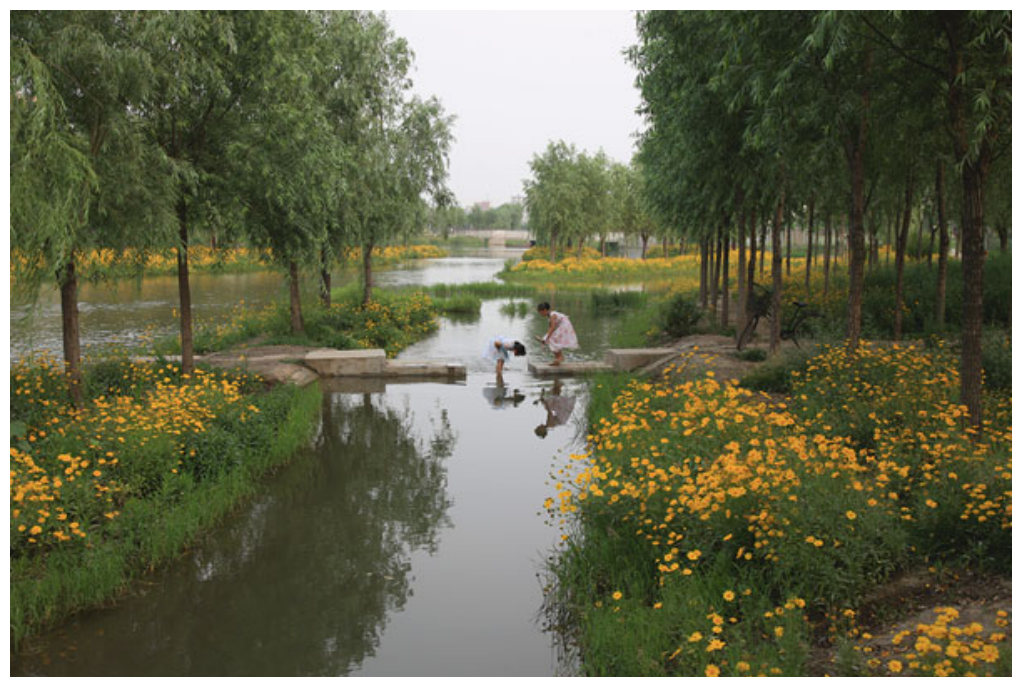

Fig. 8.7 Qian'an, China: The Sanlihe Greenway creates a water-centered public space that integrates storm water management, habitat restoration, pedestrian and bicycle pathways, everyday recreational space, and is a catalyst for new and existing urban development. Existing trees were preserved by building small "tree islands" which allow stream courses to flow around them; the groundcover is a palette of wild flowers that naturally reproduce and need little maintenance (Source: Turenscape 2010)

Finally, the last projects are those for new and expanding urban areas as exemplified in the rapidly transforming region. The first is the new Wulijie "eco-town," designed for a population of 100,000, which is located $30 \mathrm{~km}$ from the center of Wuhan, the most populous city in central China. The new city is located at the confluence of the Yangze and Han Rivers and is planned to extend to $10 \mathrm{~km}^{2}$. It is in a hilly region that has a typical Wuhan landscape that is dotted with numerous lakes and ponds. Wilijie is adjacent to Liang Zhi Hu Lake, Wuhan's drinking reservoir; therefore, the development restrictions and particularly storm water management of the site is very sensitive. Consequently, Turenscape's context-responsive water management system became the foundation of the urban development structure itself.

A water-based "ecological infrastructure" was established based on the existing landform and water network. Different rainfall potentials were simulated to determine the new size and distribution of the pond/wetland system in order that all the storm water can retained and recycled on site. In turn, the water-centered ecological infrastructure will not only reduce the construction cost of the underground drainage pipes, but also preserve and recreate habitat for native wildlife habitats. Public space and new housing typologies are developed hand-in-hand with the ecological infrastructure (Fig. 8.8). A hierarchy of three main infrastructure corridors were designed to accommodate various functions: the main corridors $(120-150 \mathrm{~m}$ wide) can manage runoff for the entire site, even during the severest storms $(200 \mathrm{~mm}$ per day); secondary corridors (60-90 m wide) work at the scale of sub-watersheds 


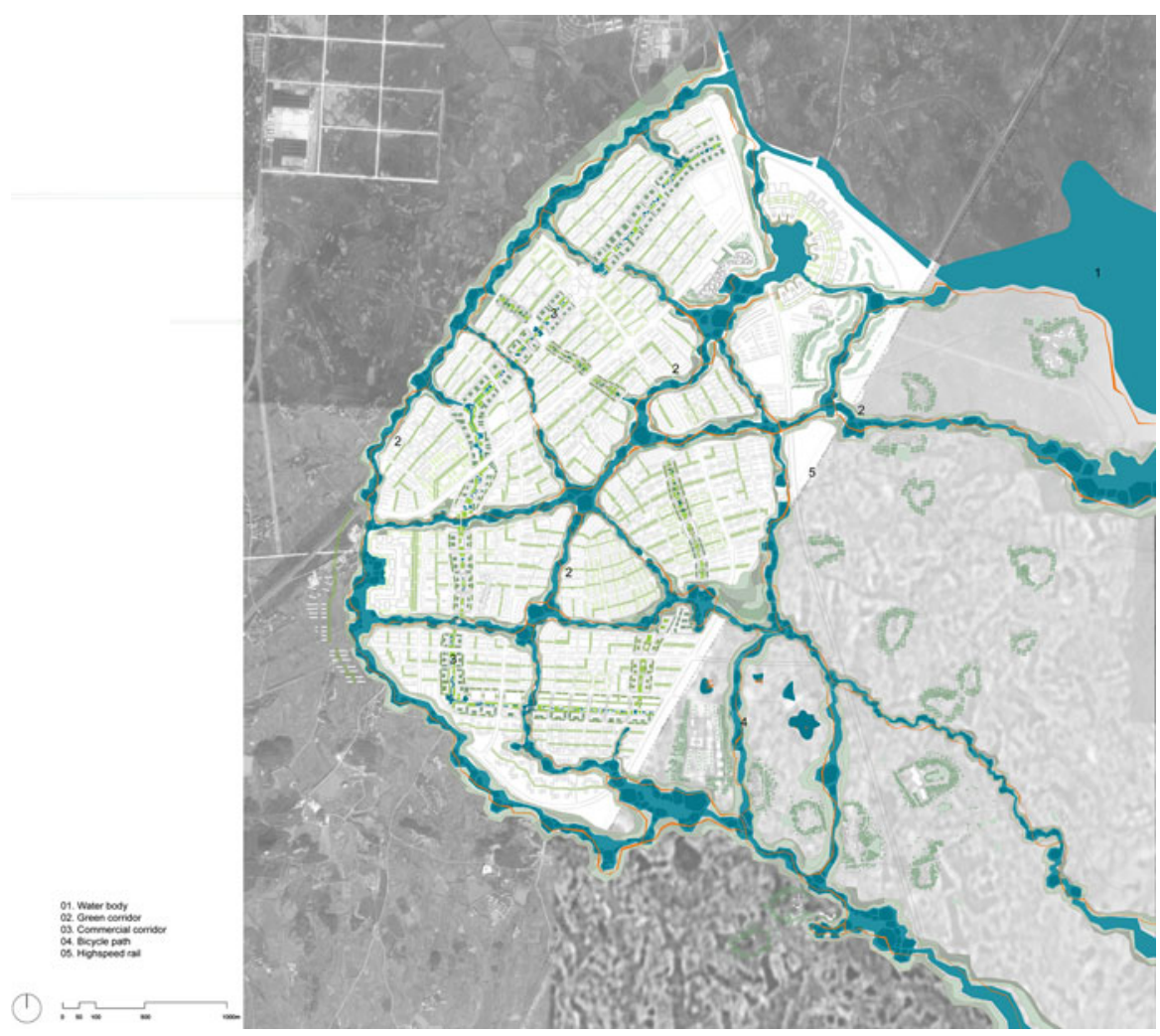

Fig. 8.8 Wilijie, China: Wuhan's new town has been structured by lakes, which in turn has established an entire repertoire of "ecological infrastructure." The water structure belies the road infrastructure and frames the urbanization and public realm (Source: Turenscape 2010)

(rains of $100 \mathrm{~mm}$ ); and the third level corridors (20-30 m wide) are suitable for than $50 \mathrm{~mm}$ per day of storm water. Integrated into the ecological infrastructure is a network of pedestrian and bicycle trails and the entire area imbues a new aesthetic environment.

Similarly, in Vietnam, ecological structures have become the basis to guide urbanization. OSA/RUA, WIT Architecten, LATITUDE with SIUP were commissioned in 2010 to revise the masterplan to 2030 for Cantho (population 1.2 million, 140,200 ha). Cantho is a city located in the heart of the enormous floodplain of the Mekong Delta, at the confluence of the Hau and Cantho Rivers. The French colonial enterprise in Indochina (1876-1954) radically transformed the Mekong Delta's watery landscape into a highly productive, irrigated territory known as Vietnam's "rice basket." Cantho is the delta's most important and rapidly urbanizing city, primarily due to rural-urban migration. The predicted effects of climate change are daunting, while its modernization process includes development of road-based 
urbanism and new engineering methods to regulate the hydraulic landscape. Accessibility and connectivity afforded by the new roads-including the recently opened Hau River Bridge—-have radically enhanced its strategic location.

Cantho's expanding territories have spatial limitations due to the intermingling of built-up environments and agricultural land, which increases the conflicting claims on the hybrid territory. These conflicting claims include urban functions versus natural or controlled floodplains, location of wastewater treatment infrastructure, water management functions versus ecological purposes. One of Cantho's largest threats is the loss of absorptive lowlands, which are filled with up to $2 \mathrm{~m}$ of soil to support urbanization. The absorptive capacity of the land is diminished as the amount of paved areas increase-with side effects of faster rainfall run-off and a lowering of the natural groundwater table. Water quantity problems are mainly related to hydrological extremes: high flow discharges and flood risks along rivers and urban drainage systems, and low flow discharges along rivers. Soft engineering approaches are proposed in order to develop Cantho as a resilient and adaptable city. A structural interweaving of hydrology, soil conditions and a new urban morphology works with the creation of a manipulated topography that rearticulates the existing logics of the territory (Fig. 8.9). The delta's agricultural territory is generated through the inscription of canal systems-pre-colonial and French-in the natural water structures that interact as warp-and-woof. The master plan envisions Cantho's future urban structure on similar lines: interweaving a green-blue structure and an urban structure. The green-blue structure defines the counter-figure for "urban platforms" on raised artificial land as the backbone of the city that inscribes itself to a large extent into the natural water structure and soil conditions. In other words, the structuring of the landscape is the foundation for a new regional and urban form. A "soft engineering" approach is addressed as a way to work with the forces of nature, in order to reduce or mitigate the likely impacts of today's increase in natural disasters, while the revised development of the city will be guided by new interplays of landscape, infrastructure and urbanization.

\section{Conclusion. Eco-engineering: From Soft to Hard \& Back}

The rise and fall of ancient civilizations and the link between precedent and experimentation leaves invaluable lessons for the contemporary world. Today, humankind is poised as heir to a triumphant age of apparent mastery over natureyet the very opposite proves true as recent disasters evince. In an era when nearly all is possible with technology and money, we have finally become more aware that consequences can be detrimental — to both cities and their wider environments. In recent decades there has been a growing environmental consciousness and a focus on sustainability. Countries such as the Netherlands are acknowledging the limits of dyke raising and ceding to soft engineering approaches in order to maximize natural flows. In the nation's Spatial Planning Key Decision, "Room for River," the relocation of dykes increase space for riverbeds and allow for greater discharges. Similarly, 


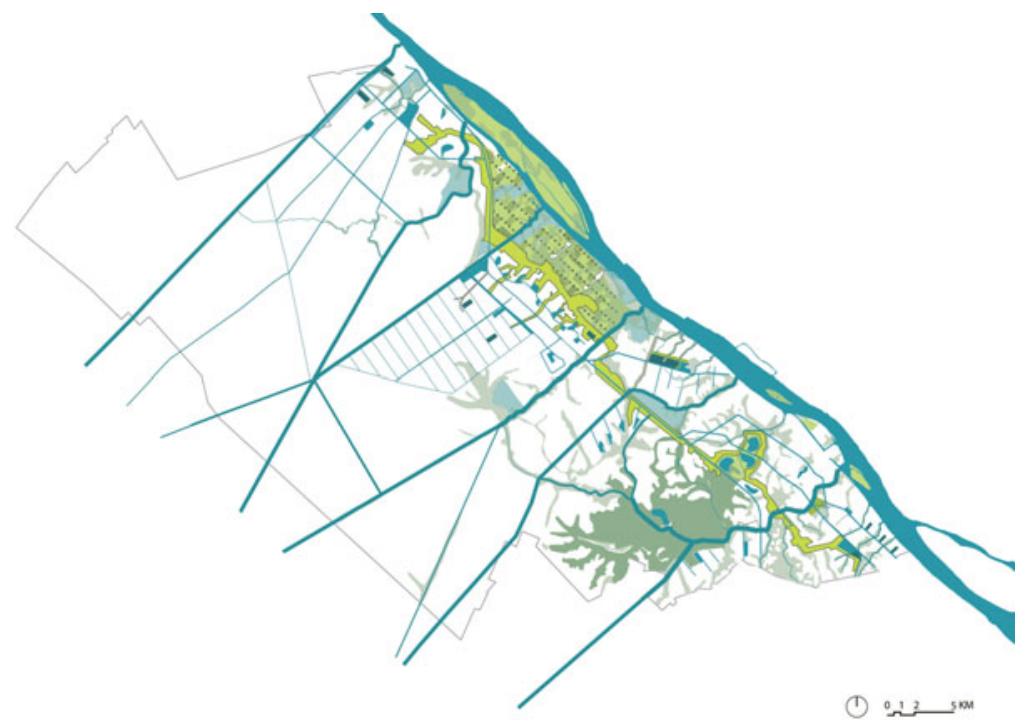

Fig. 8.9 Cantho, Vietnam: Green-blue armatures frame urbanization. The green network comprises orchards in the south, a regional-scale Hau River hi-tech agricultural park, the recreational Cantho Linear Park, more than $50 \mathrm{~km}$ long, and a tree-planting program along the "civic spine." Specific trees, unique to the territory, are planted according to topographical levels and soil conditions. The blue network addresses both water quantity (flooding, storm water retention, drainage and irrigation) and water quality (sewage, purification) by rigorously enforcing the cut-and-fill balance principle during the process of urbanization (Source: OSA/RUA/WIT/LATITUDE 2010)

de-poldering projects break dykes that once reclaimed low-lying land from the sea. The package of measures also contains interventions that leave the dyke system untouched, but increases flow capacities by lowering flood plains by stripping off top soil, lowering groynes/breakwaters thus reducing flow resistance, and removing obstacles such as bridges, old ferry piers, etc. Another interesting strategy is to introduce bypasses/flood channels in the floodplain or outside the river dykes, where they can accommodate other programs and serve as extra capacity in emergency situations controlled by new dams. Traditional dyke reinforcements are avoided unless there is no other suitable alternative.

In Asia, new greenfield sites and cities have an unprecedented opportunity to test soft-engineering strategies in combination with hard engineering - bridging the two in as novel a way as Renaissance Rome did centuries ago. Asia's ancient precedents can become invaluable to the experiments and innovation for the new cities of the future. And there are clearly interesting bridges between the soft indigenous engineering of the region's ancient civilizations and the formalization of waterworks and its inextricable relation to power, control, urban development and urban design. Urban design —in Asia or in the West—finds here one of its main future challenges, bridging new soft engineering and integral planning approaches and urban design. Or is it rather understanding again one of the main capacities of urban design: its 
ability as medium of synthesis making to integrate new soft engineering approaches in the planning and development of cities of tomorrow. With the rate of ongoing urbanization and the catastrophic shrinking of nature, these cities of tomorrow will have to find a way to redefine harmonious, though dynamic balances between city and nature. As a key element of nature, water will play a major role in that rebalancing.

\section{References}

Andoh RYG, Declerck C (1999) Source control and distributed storage: a cost effective approach to urban drainage for the new millennium? Proceedings of the 8th international conference on urban storm drainage, Sydney, Australia, 30 Aug-3 Sept 1999

Bélanger P (2009) Landscape as infrastructure. Landsc J: Des, Plan, Manage Land 28(1):79-95

De Meulder B (2008) Quays as keys: Antwerp. In: Shannon K, De Meulder B, d'Auria V, Gosseye J (eds) Water urbanisms UFO1. Sun Publishers, Amsterdam, pp 12-19

De Meulder B, Shannon K (2008) Water and the city: The 'Great Stink' and clean urbanism. In: Shannon K, De Meulder B, d'Auria V, Gosseye J (eds) Water urbanisms. Sun Publishers, Amsterdam, pp 5-9

De Meulder B, Shannon K (2009) A de-poldering project in Beveren North, Belgium. Topos 68:76-81

Feyen J, Shannon K (2008) Preface. In: Feyen J, Shannon K, Neville M (eds) Water and urban development paradigms: towards an integration of engineering, design and management approaches. CRC Press/Taylor \& Francis Group, Leiden

Gandy M (2002) Concrete and clay: reworking nature in New York city. MIT Press, Cambridge

Gandy M (2004) Rethinking urban metabolism: water, space and the modern city. City 8(3):363-379

Global Water Partnership (2011) Annual report. www.gwp.org. Accessed 15 Apr 2012

Hegewald J (2002) Water architecture in South Asia: a study of types, developments and meanings. Brill, Leiden

IPCC, Pachauri RK, Reisinger AC (eds) (2007) AR4: contribution of working groups I, II, and III to the fourth assessment of the Intergovernmental Panel on Climate Change. IPCC, Geneva

Kim HM, Han SS (2012) Seoul: city profile. Cities 29(2):142-154

Lightfoot D (2000) The origin and diffusion of Qanants in Arabia: new evidence from the northern and southern peninsula. Geogr J 166(3):215-226

Lister NM (2007) Sustainable large parks: ecological design or designer ecology. In: Czerniak J, Hargreaves G (eds) Large parks. Princeton Architectural Press, New York

Livingston M (2002) Steps to water: the ancient stepwells of India. Princeton Architectural Press, New York

Needham J (1956) Geomancy. In: Needham J (ed) Science and civilization in China, vol 2. Cambridge University Press, Cambridge

Niemczynowicz J (1999) Urban hydrology and water management: present and future challenges. Urban Water 1:1-14

Pottier C (2008) The Angkor Territory: a site for Khmer capitals. In: Siem Reap/Angkor Urban Observatory: architecture, heritage, development. IPRAUS, bulletin no. 1, Sept 2008, pp 9-10

Reed C (2006) Public works practice. In: Waldheim C (ed) Landscape urbanism reader. Princeton Architectural Press, New York, pp 267-285

Rinne K (2011) The waters of Rome: aqueducts, fountains and the birth of the baroque city. Yale University Press, New Haven

Scarborough V, Gallopin G (1991) A water storage adaptation in the Maya lowlands. Science 251:658-662 
Shannon K (2004) Rhetorics and realities. Addressing landscape urbanism. Three cities in Vietnam. Unpublished doctorate, KU Leuven

Shannon K (2008) Water urbanism: hydrological infrastructure as urban frame in Vietnam. In: Feyen J, Shannon K, Neville M (eds) Water and urban development paradigms: towards an integration of engineering, design and management approaches. Proceedings of international conference, CRC Press/Taylor \& Francis Group, Leuven, 15-17 Sept 2008, pp 55-65

Shannon K, Legrand B (2007) Aerated lagoon park in Hoc Chi Minh City, Vietnam. Topos 59:31-37

Shannon K, Manawadu S (2007) Indigenous landscape urbanism: the case of Sri Lanka. J Landsc Archit Autumn 4:30-41

Swynegedouw E (2004) Social power and the urbanization of water: flows of power. Oxford University Press, London

Topos 76 (2011) Crisis Landscapes

Wittfogel K (1956) The hydraulic civilizations. In: Thomas WL (ed) Man's role in changing the face of the Earth. University of Chicago Press, Chicago

WEPA (Water Environment Partnership in Asia) http://www.wepa-db.net/index.htm. Accessed Nov 2011

Yu K, Lei Z, Li D (2008) Living with water: flood adaptive landscapes in the Yellow River Basin of China. J Landsc Archit Autumn:6-17

www.biotope-city.net. Accessed Nov 2011 